\title{
Optimalisasi Dosis Pupuk Tunggal dan Pupuk Kandang untuk Produksi Bawang Putih di Dataran Tinggi
}

\section{Optimization of Single Dose Fertilizer and Manure for Garlic Production in the Highlands}

\author{
Ika Cartika', Abdi Hudaya ${ }^{2}$, Fahmi Aprianto ${ }^{3}$, Rini Murtiningsih ${ }^{4}$ \\ ${ }^{1,2,3,4}$ Balai Penelitian Tanaman Sayuran, Lembang Jawa Barat
}

\section{ARTICLE INFO \\ Article history: \\ DOI: \\ $\underline{10.30595 / p s p f s . v 2 i .168}$}

Submitted:

July 29, 2021

Accepted:

Sept 10, 2021

Published:

Nov 10, 2021

\section{Keywords:}

Garlic, Manure, Single Fertilizer

\begin{abstract}
The addition of nutrients for garlic plants consists of two type, namely the application of anorganic fertilizers in the form of single fertilizers $\mathrm{N}, \mathrm{P}, \mathrm{K}$ and organic fertilizers such as manure. The purpose of this study was to obtain the right dose of single fertilizer N, P, K and chicken manure. The experiment was arranged using a Randomized Block Design with 4 replications. The treatments consisted of 9 treatment combinations consisting of $\mathrm{A}=100 \%$ single fertilizer +15 tons of manure, $\mathrm{B}=100 \%$ single fertilizer +10 tons of manure, $\mathrm{C}=100 \%$ single fertilizer +5 tons of manure, $\mathrm{D}=75 \%$ single fertilizer +15 tons of manure, $\mathrm{E}=75 \%$ single fertilizer +10 tons of manure, $\mathrm{F}=75 \%$ single fertilizer +5 tons of manure, $\mathrm{G}=50 \%$ single fertilizer +15 tons of manure, $\mathrm{H}=50 \%$ single fertilizer + 10 tons of manure, $\mathrm{I}=50 \%$ single fertilizer +5 tons of manure. The dose of $100 \%$ single fertilizer was SP36 375 kg.ha-1, ZA $1.144 \mathrm{~kg}$.ha-1 and KCl $200 \mathrm{~kg}$.ha- 1 . The type of manure used is chicken manure. The results showed that doses of $75 \%$ and $100 \%$ of single fertilizer combined with 15 ton.ha-1 resulted in the wet and dry weight of the stover, the diameter and weight of the tubers, which were the same, respectively, the dry weight of the stover 32,57 grams and 39,40 grams, the dry weight of the stover. 17,43 grams and 17,63 grams, tuber diameter 33,09 and 33,13, tuber weight 14,07 grams and 14,30 grams. These results tend to be higher than other treatments. $75 \%$ single fertilizer and 15 ton.ha-1 chicken manure can be recommended for fertilization in garlic production.
\end{abstract}

This work is licensed under a Creative Commons Attribution 4.0 International License.

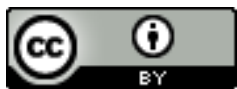

Corresponding Author:

Ika Cartika

Balai Penelitian Tanaman Sayuran, Lembang Jawa Barat

Email: balitsa@ litbang.pertanian.go.id

\section{PENDAHULUAN}

Bawang putih adalah jenis tanaman subtropik yang biasa ditanam pada musim semi dan dipanen pada musim panas. Suhu yang cocok adalah kurang lebih $20{ }^{\circ} \mathrm{C}$, sehingga jika bawang putih ditanam di Indonesia yang paling cocok adalah pada daerah dataran tinggi dengan ketinggian diatas 1.000 meter diatas permukaan laut (Sutaman, 2019).

Tanaman bawang putih memerlukan ketersediaan hara dalam jumlah yang cukup dan berimbang agar dapat tumbuh dan berproduksi optimal, Unsur hara yang dibutuhkan tanaman bisa didapat dengan penambahan pupuk anorganik. Penambahan unsur hara dalam tanah dengan pupuk anorganik bisa menggunakan jenis pupuk tunggal. Pupuk tunggal yaitu pupuk yang mengandung hanya satu jenis unsur hara sebagai penambah kesuburan. Contoh pupuk tunggal yaitu pupuk nitrogen $(\mathrm{N})$, fosfor (P) dan kalium (K) (Rajiman, 2020). 
Keuntungan penggunaan pupuk tunggal adalah cepat larut sehingga dapat mengurangi pencucian hara dan dapat digunakan pada semua jenis tanaman dan sesuai dengan kebutuhan (Anggraini dkk., 2019). Tanaman bawang putih memerlukan unsur N, P dan K yang cukup besar. Menurut Basuki dkk. (2019) bawang putih memerlukan pupuk SP36 $375 \mathrm{~kg} / \mathrm{ha}$, ZA $1.144 \mathrm{~kg} / \mathrm{ha}$ dan $\mathrm{KCl} 200 \mathrm{~kg} / \mathrm{ha}$.

Selain jenis pupuk anorganik, pemberian pupuk organik perlu dilakukan untuk memperbaiki sifat fisik, kimia dan biologi tanah, serta mampu meningkatkan aktivitas mikroorganisme tanah dalam tanah (Supariadi dkk., 2017). Jenis pupuk organik yang banyak digunakan di daerah dataran tinggi adalah pupuk kandang ayam. Keuntungan penggunaan pupuk kandang ayam adalah mudah didapat dan mengandung hara 2.44\% N, 10,67\% $\mathrm{P}_{2} \mathrm{O}_{5}, 1,24 \% \mathrm{~K}_{2} \mathrm{O}$, dan $16.0 \%$ C-organik (Kurnia dkk., 2016). Pupuk kandang ayam mengandung unsur hara $\mathrm{N}$, $\mathrm{P}, \mathrm{K}$, dan Ca lebih tinggi dibandingkan pupuk kandang hewan yang lainnya (Fitrah \& Amir, 2015). Menurut Basuki dkk. (2019) untuk menghasilkan produksi yang optimal, bawang putih memerlukan dosis pupuk kandang ayam sebanyak 15 ton/ha.

Penggunaan pupuk anorganik tanpa diimbangi dengan pemakaian pupuk organik akan mengurangi produktivitas lahan. Oleh karenanya perlu adanya informasi tentang dosis aplikasi pemupukan pupuk organik dengan pupuk organik yang tepat guna menjaga kesuburan tanah dan meningkatkan produksi bawang putih. Penelitian ini bertujuan untuk mendapatkan dosis kombinasi pupuk anorganik dan pupuk organik yang tepat dalam produksi bawang putih di dataran tinggi.

\section{METODE PENELITIAN}

\section{Bahan}

Bahan yang digunakan dalam penelitian ini adalah benih bawang putih varietas lumbu hijau, pupuk ZA, SP36, $\mathrm{KCl}$, dan pupuk kandang ayam .

\section{Metode}

Percobaan dilaksanakan di kebun percobaan Margahayu Balai Penelitian Tanaman Sayuran Lembang, Jawa Barat, dengan ketinggian 1250 m diatas permukaan laut. Percobaan berlangsung dari bulan Mei sampai September 2019. Rancangan percobaan menggunakan rancangan acak kelompok (RAK) yang terdiri dari 9 perlakuan yaitu:
$\mathrm{A}=100 \%$ Pupuk Tunggal (375 kg.ha ${ }^{-1}$ SP36, $\left.1144 \mathrm{~kg} \cdot \mathrm{ha}^{-1} \mathrm{ZA}, 200 \mathrm{~kg} \cdot \mathrm{ha}^{-1} \mathrm{KCl}\right)+15$ ton.ha Pupuk $^{-}$ kandang
$\mathrm{B}=100 \%$ Pupuk Tunggal (375 kg.ha ${ }^{-1}$ SP36, $\left.1144 \mathrm{~kg} \cdot \mathrm{ha}^{-1} \mathrm{ZA}, 200 \mathrm{~kg} \cdot \mathrm{ha}^{-1} \mathrm{KCl}\right)+10$ ton.ha Pupuk $^{-}$ kandang
$\mathrm{C}=100 \%$ Pupuk Tunggal $\left(375 \mathrm{~kg} \cdot \mathrm{ha}^{-1} \mathrm{SP} 36,1144 \mathrm{~kg} \cdot \mathrm{ha}^{-1} \mathrm{ZA}, 200 \mathrm{~kg} \cdot \mathrm{ha}^{-1} \mathrm{KCl}\right)+5$ ton.ha Pupuk $^{-}$ kandang
$\mathrm{D}=75 \%$ pupuk tunggal $\left(281,25 \mathrm{~kg} \cdot \mathrm{ha}^{-1} \mathrm{SP} 36,858 \mathrm{~kg} \cdot \mathrm{ha}^{-1} \mathrm{ZA}, 150 \mathrm{~kg} \cdot \mathrm{ha}^{-1} \mathrm{KCl}\right)+15$ ton.ha- Pupuk kandang
$\mathrm{E}=75 \%$ pupuk tunggal $\left(281,25 \mathrm{~kg} \cdot \mathrm{ha}^{-1} \mathrm{SP} 36,858 \mathrm{~kg} \cdot \mathrm{ha}^{-1} \mathrm{ZA}, 150 \mathrm{~kg} \cdot \mathrm{ha}^{-1} \mathrm{KCl}\right)+10$ ton.ha ${ }^{-}$Pupuk kandang
$\mathrm{F}=75 \%$ pupuk tunggal $\left(281,25 \mathrm{~kg} \cdot \mathrm{ha}^{-1} \mathrm{SP} 36,858 \mathrm{~kg} \cdot \mathrm{ha}^{-1} \mathrm{ZA}, 150 \mathrm{~kg} \cdot \mathrm{ha}^{-1} \mathrm{KCl}\right)+5$ ton.ha Pupuk kandang $^{-1}$
$\mathrm{G}=50 \%$ pupuk tunggal $\left(187,5 \mathrm{~kg} \cdot \mathrm{ha}^{-1} \mathrm{SP} 36,575 \mathrm{~kg} \cdot \mathrm{ha}^{-1} \mathrm{ZA}, 100 \mathrm{~kg} \cdot \mathrm{ha}^{-1} \mathrm{KCl}\right)+15$ ton.ha Pupuk kandang
$\mathrm{H}=50 \%$ pupuk tunggal $\left(187,5 \mathrm{~kg} \cdot \mathrm{ha}^{-1} \mathrm{SP} 36,575 \mathrm{~kg} \cdot \mathrm{ha}^{-1} \mathrm{ZA}, 100 \mathrm{~kg} \cdot \mathrm{ha}^{-1} \mathrm{KCl}\right)+10$ ton.ha $\mathrm{H}^{-}$Pupuk kandang
$\mathrm{I}=50 \%$ pupuk tunggal $\left(187,5 \mathrm{~kg} \cdot \mathrm{ha}^{-1} \mathrm{SP} 36,575 \mathrm{~kg} \cdot \mathrm{ha}^{-1} \mathrm{ZA}, 100 \mathrm{~kg} \cdot \mathrm{ha}^{-1} \mathrm{KCl}\right)+5$ ton.ha Pupuk kandang $^{-}$

Aplikasi pupuk kandang dan pupuk SP36 diberikan 2 minggu sebelum tanam. Sementara pupuk ZA dan KCl diaplikasikan empat kali yaitu pada umur 21, 35, 49 dan 63 hari setelah tanam. Setiap kali aplikasi dosis pupuk $\mathrm{ZA}$ dan $\mathrm{KCl}$ untuk perlakuan $100 \%$ pupuk tunggal yaitu $286 \mathrm{~kg} \cdot \mathrm{ha}^{-1} \mathrm{ZA}$ dan $50 \mathrm{~kg} \cdot \mathrm{ha}^{-1} \mathrm{KCl}$, perlakuan $75 \%$ pupuk tunggal yaitu $214,5 \mathrm{~kg} \cdot \mathrm{ha}^{-1} \mathrm{ZA}$ dan $37,5 \mathrm{~kg} \cdot \mathrm{ha}^{-1} \mathrm{KCl}$, dan perlakuan $50 \%$ pupuk tunggal yaitu 143,75 $\mathrm{kg} . \mathrm{ha}^{-1} \mathrm{ZA}$ dan $25 \mathrm{~kg} \cdot \mathrm{ha}^{-1} \mathrm{KCl}$.

\section{HASIL DAN PEMBAHASAN}

\section{Tingi Tanaman (cm) dan Jumlah Daun}

Hasil analisis ragam pada tinggi tanaman dan jumlah daun menunjukan kombinasi dosis pupuk tunggal dan pupuk kandang berpengaruh tidak nyata. rata-rata tinggi tanaman dan jumlah daun hasil uji jarak berganda Duncan pada taraf 5\% disajikan pada Tabel 1. Pada tabel 1 dapat dilihat bahwa walaupun semua perlakuan tidak berbeda nyata tapi dengan peningkatan dosis kombinasi pupuk tunggal dan pupuk kandang menyebabkan peningkatan tinggi tanaman. Hal ini diduga karena penambahan pupuk tunggal akan menyediakan unsur hara yang dibutuhkan tanaman lebih tersedia, dan fungsi pupuk kandang yang mampu memperbaiki struktur tanah akan mempertinggi daya serap dan daya simpan air, yang secara keseluruhan mampu meningkatkan kesuburan tanah (Hartatik \& Widowati, 2006). Dengan tanah yang lebih subur, akar akan lebih mudah menyerap unsur 
hara yang terkandung dalam tanah. Unsur hara yang diserap oleh akar digunakan oleh tanaman untuk meningkatkan pertumbuhan tinggi tanaman (Kurnia dkk., 2016).

Pertambahan jumlah daun sebanding dengan pertambahan tinggi tanaman. Kedua parameter tersebut tidak dipengaruhi secara nyata oleh aplikasi pupuk tunggal dan pupuk kandang. Hal ini sependapat dengan Haryadi dkk., (2015) bahwa jumlah daun berhubungan dengan parameter tinggi tanaman, semakin tinggi tanaman maka semakin banyak daun yang terbentuk. Sementara menurut Raga dkk., (2012) jumlah daun dipengaruhi oleh faktor genetik dan tidak dipengaruhi oleh lingkungan.

Tabel 1. Rata-rata Tinggi Tanaman dan Diameter Batang Bawang Putih dengan Beberapa Dosis Pupuk Tunggal N, P, K dan Pupuk Organik

\begin{tabular}{|c|c|c|c|c|c|}
\hline \multicolumn{2}{|r|}{ Perlakuan } & \multicolumn{2}{|c|}{$\begin{array}{l}\text { Tinggi Tanaman } \\
(\mathrm{cm})\end{array}$} & \multicolumn{2}{|c|}{$\begin{array}{c}\text { Jumlah Daun } \\
\text { (Helai) }\end{array}$} \\
\hline A. & $100 \%$ Pupuk tunggal +15 ton Pupuk kandang & 59,29 & $\mathrm{a}$ & 7,00 & $\mathrm{a}$ \\
\hline B. & $100 \%$ Pupuk tunggal +10 ton Pupuk kandang & 58,22 & $\mathrm{a}$ & 6,67 & a \\
\hline C. & $100 \%$ Pupuk tunggal +5 ton Pupuk kandang & 56,25 & a & 6,33 & a \\
\hline D. & $75 \%$ Pupuk tunggal +15 ton Pupuk kandang & 56,42 & a & 6,33 & a \\
\hline E. & $75 \%$ Pupuk tunggal +10 ton Pupuk kandang & 55,66 & a & 6,33 & a \\
\hline F. & $75 \%$ Pupuk tunggal +5 ton Pupuk kandang & 55,50 & a & 6,33 & a \\
\hline G. & $50 \%$ Pupuk tunggal +15 ton Pupuk kandang & 54,47 & a & 6,33 & a \\
\hline $\mathrm{H}$. & $50 \%$ Pupuk tunggal +10 ton Pupuk kandang & 53,83 & a & 6,33 & a \\
\hline I. & $50 \%$ Pupuk tunggal +5 ton Pupuk kandang & 53,94 & $\mathrm{a}$ & 6,00 & $\mathrm{a}$ \\
\hline
\end{tabular}

Angka yang diikuti oleh huruf kecil yang sama pada kolom yang sama tidak berbeda nyata menurut uji jarak berganda Duncan pada taraf 5\%

\section{Diameter Batang \& Panjang Akar}

Hasil analisis ragam pada diameter batang dan panjang akar menunjukkan bahwa kombinasi pupuk tunggal dan pupuk kandang berpengaruh nyata terhadap diameter batang dan panjang akar. Rata-rata diameter batang dan panjang akar hasil uji jarak berganda Duncan pada taraf 5\% disajikan pada Tabel 2.

Tabel 2. Rata-rata Diameter Batang dan Panjang Akar Bawang Putih dengan Beberapa Dosis Pupuk Tunggal N, P, K dan Pupuk Organik

\begin{tabular}{|c|c|c|c|c|c|}
\hline \multicolumn{2}{|r|}{ Perlakuan } & \multicolumn{2}{|c|}{$\begin{array}{l}\text { Diameter Batang } \\
(\mathrm{mm})\end{array}$} & \multicolumn{2}{|c|}{$\begin{array}{l}\text { Panjang Akar } \\
(\mathrm{cm})\end{array}$} \\
\hline A. & $100 \%$ Pupuk tunggal +15 ton Pupuk kandang & 10,22 & $\mathrm{~b}$ & 12,28 & $\mathrm{~b}$ \\
\hline B. & $100 \%$ Pupuk tunggal +10 ton Pupuk kandang & 9,73 & $a b$ & 11,33 & $a b$ \\
\hline C. & $100 \%$ Pupuk tunggal +5 ton Pupuk kandang & 9,43 & $a b$ & 10,97 & $a b$ \\
\hline D. & $75 \%$ Pupuk tunggal +15 ton Pupuk kandang & 9,80 & $\mathrm{ab}$ & 11,30 & $\mathrm{ab}$ \\
\hline E. & $75 \%$ Pupuk tunggal +10 ton Pupuk kandang & 9,58 & $a b$ & 11,20 & $\mathrm{ab}$ \\
\hline F. & $75 \%$ Pupuk tunggal +5 ton Pupuk kandang & 9,30 & $a b$ & 10,47 & $\mathrm{ab}$ \\
\hline G. & $50 \%$ Pupuk tunggal +15 ton Pupuk kandang & 8,99 & $\mathrm{a}$ & 10,90 & $\mathrm{ab}$ \\
\hline H. & $50 \%$ Pupuk tunggal +10 ton Pupuk kandang & 8,96 & a & 10,90 & $a b$ \\
\hline I. & $50 \%$ Pupuk tunggal +5 ton Pupuk kandang & 8,87 & $\mathrm{a}$ & 10,20 & $\mathrm{a}$ \\
\hline
\end{tabular}

Angka yang diikuti oleh huruf kecil yang sama pada kolom yang sama tidak berbeda nyata menurut uji jarak berganda Duncan pada taraf 5\%

Kombinasi $100 \%$ pupuk tunggal +15 ton pupuk kandang menghasilkan diameter batang yaitu $10.22 \mathrm{~cm}$ hanya berbeda nyata dengan dosis 50\% pupuk tunggal yang dikombinasikan dengan 15, 10 dan 5 ton pupuk kandang. Hal ini diduga karen pemberian pupuk dosis $100 \%$ pupuk tunggal +15 ton pupuk kandang lebih mampu memperbaiki sifak fisik, kimia dan biologi tanah sehingga unsur hara didalam tanah seperti unsur $\mathrm{N}$ yang dibutuhkan tanaman dapat terpenuhi. Menurut Supariadi dkk. (2017) asam amino yang banyak terkandung dalam pupuk kandang akan meningkatkan keaktifan mikroorganisme pengurai dalam pupuk kandang, sehingga mempercepat pelapukan dan meningkatkan ketersedian unsur hara dalam tanah.

Kombinasi $100 \%$ pupuk tunggal +15 ton pupuk kandang menghasilkan panjang akar tertinggi yaitu $12.28 \mathrm{~cm}$, tetapi hanya berbeda nyata dengan dosis $50 \%$ pupuk tunggal yang dikombinasikan dengan 5 ton pupuk kandang. Sementara dengan perlakuan lainnya tidak berbeda nyata. Pemupukan dimaksudkan untuk memperbaiki kekurangan unsur hara dalam tanah. Dengan pemupukan, tanaman secara langsung memperoleh unsur yang tersedia yang segera dapat diambil oleh sistem perakaran (Kurniawan dkk., 2014). Diduga penambahan perlakuan pupuk N, P, K dan pupuk kandang kecuali pada dosis $50 \%$ pupuk tunggal +5 ton pupuk kandang cukup mampu untuk mengikat air dan menyediakan unsur hara yang dibutuhkan tanaman, membuat 
drainase dan aerasi pada media tanam yang baik, bisa menjaga kelembaban disekitar perkaran tanaman sehingga panjang akar akan tumbuh optimal. Pemberian unsur $\mathrm{N}$ yang optimal dapat meningkatkan sintesis protein dan meningkatkan panjang akar.

\section{Bobot Basah dan Bobot Kering Brangkasan}

Hasil analisis ragam pada bobot basah dan kering brangkasan menunjukkan bahwa kombinasi pupuk tunggal dan pupuk kandang ayam berpengaruh nyata pada bobot basah brangkasan, tetapi tidak berpengaruh nyata pada bobot kering brangkasan. Kombinasi $100 \%$ pupuk tunggal +15 ton pupuk kandang menghasilkan bobot basah yang sama dengan kombinasi $75 \%$ pupuk tunggal +15 ton pupuk kandang, tetapi lebih tinggi dbanding dengan kombinasi perlakuan lainnya.

Tabel 3. Rata-rata Bobot Basah dan Kering Brangkasan Bawang Putih dengan Beberapa Dosis Pupuk Tunggal N, P, K dan Pupuk Organik

\begin{tabular}{|c|c|c|c|c|c|}
\hline \multicolumn{2}{|r|}{ Perlakuan } & \multicolumn{2}{|c|}{$\begin{array}{l}\text { Bobot basah } \\
\text { brangkasan } \\
\text { (gram) }\end{array}$} & \multicolumn{2}{|c|}{$\begin{array}{c}\text { Bobot kering } \\
\text { brangkasan } \\
\text { (gram) }\end{array}$} \\
\hline A. & $100 \%$ Pupuk tunggal +15 ton Pupuk kandang & 39,40 & $\mathrm{~b}$ & 17,63 & $\mathrm{~b}$ \\
\hline B. & $100 \%$ Pupuk tunggal +10 ton Pupuk kandang & 30,50 & $\mathrm{a}$ & 16,07 & $a b$ \\
\hline C. & $100 \%$ Pupuk tunggal +5 ton Pupuk kandang & 28,83 & a & 14,60 & $\mathrm{a}$ \\
\hline D. & $75 \%$ Pupuk tunggal +15 ton Pupuk kandang & 32,57 & $a b$ & 17,43 & $\mathrm{~b}$ \\
\hline E. & $75 \%$ Pupuk tunggal +10 ton Pupuk kandang & 26,70 & a & 14,47 & $\mathrm{a}$ \\
\hline F. & $75 \%$ Pupuk tunggal + 5 ton Pupuk kandang & 24,80 & a & 13,80 & $\mathrm{a}$ \\
\hline G. & $50 \%$ Pupuk tunggal +15 ton Pupuk kandang & 27,87 & a & 13,60 & $\mathrm{a}$ \\
\hline H. & $50 \%$ Pupuk tunggal +10 ton Pupuk kandang & 25,03 & $\mathrm{a}$ & 13,26 & $\mathrm{a}$ \\
\hline I. & $50 \%$ Pupuk tunggal +5 ton Pupuk kandang & 24,50 & $\mathrm{a}$ & 13,20 & $\mathrm{a}$ \\
\hline
\end{tabular}

Angka yang diikuti oleh huruf kecil yang sama pada kolom yang sama tidak berbeda nyata menurut uji jarak berganda Duncan pada taraf $5 \%$

Unsur N, P, K dalam tanah sangat menentukan bobot tanaman. Nitrogen merupakan penysusun $50 \%$ protoplasma, sehingga jika unsur $\mathrm{N}$ terpenuhi maka bobot basah dan kering tanaman akan optimal (Tisdal dan Nelson, 1975). Penambahan $75 \%$ dan $100 \%$ pupuk tunggal yang dikombinasikan dengan 15 ton pupuk kandang diduga mampu memenuhi kebutuhan hara yang diperlukan bawang putih untuk membentuk jaringan tanaman yang optimal. Menurut Yassen dkk., (2018) Unsur K juga berpengaruh dalam meningkatkan berat kering bawang merah selain unsur $\mathrm{N}$.

\section{Diameter dan Bobot Umbi}

Hasil analisis ragam diameter dan bobot umbi menunjukan bahwa kombinasi dosis pupuk tunggal dan pupuk kandang ayam berpengaruh nyata terhadap diameter umbi dan bobot umbi. Kombinasi $100 \%$ pupuk tunggal +15 ton pupuk kandang dan $75 \%$ pupuk tunggal +15 ton pupuk kandang menghasilkan diameter umbi dan bobot umbi yang sama yaitu masing-masing diameter umbi 33,13 gram dan 33,09 gram, bobot umbi 14,30 gram dan 14,07 gram. Akan tetapi kedua perlakuan tersebut hanya berbeda nyata dengan kombinasi $50 \%$ pupuk tunggal +5 ton pupuk kandang. sementara dengan perlakuan lainnya tidak berbeda nyata.

Tabel 4. Rata-rata Diameter dan Bobot Umbi Bawang Putih dengan Beberapa Dosis Pupuk Tunggal N, P, K dan Pupuk Organik

\begin{tabular}{|c|c|c|c|c|c|}
\hline \multicolumn{2}{|r|}{ Perlakuan } & \multicolumn{2}{|c|}{$\begin{array}{l}\text { Diameter umbi } \\
\qquad(\mathrm{mm})\end{array}$} & \multicolumn{2}{|c|}{$\begin{array}{l}\text { Bobot umbi } \\
\text { (gram) }\end{array}$} \\
\hline A. & $100 \%$ Pupuk tunggal +15 ton Pupuk kandang & 33,13 & $\mathrm{~b}$ & 14,30 & $\mathrm{~b}$ \\
\hline B. & $100 \%$ Pupuk tunggal +10 ton Pupuk kandang & 32,87 & $a b$ & 13,60 & $a b$ \\
\hline C. & $100 \%$ Pupuk tunggal +5 ton Pupuk kandang & 31,73 & $a b$ & 12,23 & $\mathrm{ab}$ \\
\hline D. & $75 \%$ Pupuk tunggal +15 ton Pupuk kandang & 33,09 & $\mathrm{~b}$ & 14,07 & $\mathrm{~b}$ \\
\hline E. & $75 \%$ Pupuk tunggal +10 ton Pupuk kandang & 31,81 & $a b$ & 11,57 & $a b$ \\
\hline F. & $75 \%$ Pupuk tunggal +5 ton Pupuk kandang & 31,15 & $a b$ & 11,40 & $a b$ \\
\hline G. & $50 \%$ Pupuk tunggal +15 ton Pupuk kandang & 30,68 & $a b$ & 11,27 & $a b$ \\
\hline H. & $50 \%$ Pupuk tunggal +10 ton Pupuk kandang & 30,49 & $a b$ & 11,17 & $\mathrm{ab}$ \\
\hline I. & $50 \%$ Pupuk tunggal +5 ton Pupuk kandang & 29,98 & $\mathrm{a}$ & 10,97 & $\mathrm{a}$ \\
\hline
\end{tabular}


Unsur hara K sangat diperlukan dalam pembentukan, pembesaran dan pemanjangan umbi (Ispandi, 2003). Keseimbangan unsur hara $\mathrm{K}$ dan $\mathrm{P}$ di dalam tanah sangat berperan dalam sintesis karbohidrat dan protein sehingga sangat membantu memperbesar umbi bawang merah (Sutrisna dkk., 2003). Hasil diameter dan bobot umbi yang rendah dari dosis $50 \%$ pupuk tunggal dan 5 ton pupuk kandang diduga kurang memenuhi unsur $\mathrm{N}, \mathrm{P}$, K yang dibutuhkan tanaman bawang putih. Menurut Wahyudi dkk., ( 2014) bahwa aplikasi pupuk kandang ayam 30 ton/ha menghasilkan diameter umbi dan bobot segar umbi lebih tinggi dibandingkan dengan 10 dan 20 ton.ha ${ }^{-1}$. Sementara hasil penelitian bahwa dosis pupuk kandang 15 ton dan 10 ton.ha ${ }^{-1}$ menghasilkan diameter dan bobot umbi yang sama. Ini berarti bahwa pemakaian pupuk kandang bisa dihemat dengan hanya menggunakan dosis 10 ton/ha.

\section{KESIMPULAN}

Semua perlakuan memberikan tinggi tanaman dan jumlah daun yang sama. Perlakuan $75 \%$ dan $100 \%$ pupuk tunggal yang dikombinasikan dengan 5, 10 dan 15 ton.ha ${ }^{-1}$ pupuk kandang ayam menghasilkan diameter batang dan panjang akar yang sama. Dosis $75 \%$ dan 100\% pupuk tunggal yang dikombinasikan dengan 15 ton.ha ${ }^{-1}$ menghasilkan bobot umbi, diameter umbi, bobot basah dan kering brangkasan yang sama, masingmasing diameter umbi 33,09 $\mathrm{mm}$ dan $33,13 \mathrm{~mm}$, bobot umbi 14,07 gram dan 14,30 gram, bobot basah brangkasan 32,57 gram dan 39,40 gram, bobot kering brangkasan 17,43 gram dan 17,63 gram.

\section{DAFTAR PUSTAKA}

Anggraini, M., Hastuti, D., \& Rohmawati, I. (2019). Pengaruh bobot umbi dan dosis kombinasi pupuk anorganik terhadap pertumbuhan dan hasil bawang merah (Allium ascalonicum L .). Jurnal Ilmu Pertanian Tirtayasa, 1(1), 37-47.

Basuki, R., Efendi, A., \& Hermanto, C. (2019). Teknologi inovatif budidaya bawang putih. Bandung Barat: Balai Penelitian Tanaman Sayuran.

Fitrah, A., \& Amir, N. (2015). Pengaruh jenis pupuk organik padat dan cair terhadap pertumbuhan dan produksi tanaman seledri (Apium graveolens L.) di polybag. Klorofil, 10(1), 43-48.

Hartatik, W., \& Widowati, L. . (2006). Pupuk kandang. In Pupuk Organik dan Pupuk Hayati (pp. 59-82).

Haryadi, D., Yetti, H., \& Yoseva, S. (2015). Pengaruh pemberian beberapa jenis pupuk terhadap pertumbuhan dan produksi tanaman kailan. JOM Faperta, 2(2), 1-10. https://doi.org/10.11164/jjsps.5.2_381_2.

Ispandi, A. (2003). Pemupukan P, K dan waktu pemberian pupuk K pada tanaman ubikayu di lahan kering vertisol. Ilmu Pertanian, 10(2), 35-50.

Kurnia, K. M., Pasigai, A., \& Wahyudi, I. (2016). Pengaruh pupuk kandang ayam terhadap pertumbuhan dan hasil tanaman kubis bunga pada Oxic dystrudepts lembantongoa. Agrotekbis, 4(2), 151-159.

Kurniawan, S., Bintoro, A., \& Riniarti, M. (2014). Pengaruh beberapa dosis pupuk dan beberapa media tumbuh terhadap pertumbuhan bibit jabon (Anthocephalus cadamba). Jurnal Sylva Lestari, 2(1), 31-40.

Raga, Y. P., Haryati, \& Lisa, M. (2012). Respon pertumbuhan dan hasil bawang sabrang pada beberapa jarak tanam dan berbagai tingkat pemotongan umbi bibit. Jurnal Online Agroteknologi, 1(1), 159-171.

Rajiman, R. (2020). Pengantar pemupukan. Yogyakarta: Deepublish.

Supariadi, Yetti, H., \& Yoseva, S. (2017). Pengaruh pemberian pupuk kandang dan pupuk N, P, dan K terhadap pertumbuhan dan produksi tanaman bawang merah (Allium ascalonicum L.). JOM Faperta, 4(1), 1-12.

Sutaman. (2019). Budidaya Bawang Putih. Retrieved from http://cybex.pertanian.go.id/mobile/artikel/65132/Budidaya-Bawang-Putih/

Sutrisna, N., Suwalan, S., \& Ishaq, I. (2003). Uji kelayakan teknis dan finansial penggunaan pupuk NPK anorganik pada tanaman kentang dataran tinggi di Jawa Barat. Jurnal Hortikultura, 13(1), 67-75. https://doi.org/10.21082/jhort.v13n1.2003.p67-75.

Wahyudi, A., Zulqarnida, M., \& Widodo, S. (2014). Aplikasi pupuk organik dan anorganik dalam budidaya bawang putih varietas lumbu hijau. Prosiding Seminar Nasional Pengembangan Teknologi Pertanian, (May 2014), 237-243.

Yassen, A., Abou ELNour, E., Abou Seeda, M., Abdallah, M., \& El-Sayed, S. (2018). Effect of potassium fertilization levels and algae extract on growth, bulb yield and quality of onion (Allium cepa L.). Middle East Journal of Agriculture Research, 7(2), 625-638. 